\title{
Membentuk Sumber Daya Manusia dengan Pondasi Ihsan melalui Emotional and Spiritual Quotient (ESQ)
}

\author{
Edi Suranta \\ Sekolah Tinggi Ilmu Ekonomi Tribuana \\ edisuranta@stietribuana.ac.id
}

\begin{abstract}
The Italian philosopher Macevelli, who lived in the 15th-16th century AD, proclaimed that to achieve the goal of a nation-state society to achieve the goal of all means can be taken as long as the goal is achieved, tricks, tricks, and even actions that are contrary to conscience can be done. The war of right thinking is happening at this time with the help of propaganda through electronic media and mass media as it is now, in building opinions. The change in influence is so real and clear. Theories and ideas put into practice that were once politically marginalized now control the state. ESQ is here to answer the $S Q$ theory, the fruit of Ari Ginanjar's thought as a role model for spiritual training guided by the pillars of faith and the pillars of Islam, which adorn cultural understanding and work ethic back to human nature such as love, honesty, responsibility, caring, discipline, togetherness, peace, back in orbit.
\end{abstract}

Keyword: Human Resources, ESQ

\section{Abstrak}

Filosuf italia Macevelli yang hidup diabad 15 - 16 M memproklamirkan bahwa untuk mencapai tujuan bermasyarakat berbangsa bernegara untuk mencapai tujuan segala cara dapat ditempuh asalkan tujuan tercapai, tipu daya, trik, bahkan tindakan yang bertentangan dengan hati nurani bisa dilakukan. Perang pemikiran benar terjadi pada saat ini dengan dibantu propaganda melalui media elektronik maupun media massa seperti sekarang, dalam membangun opini . Perubahan pengaruh sebegitu nyata dan terang benderang. Teori dan pemikiran dipraktekkan yang dulu termarjinalkan secara politik sekarang mengendalikan negara. ESQ hadir menjawab atas teori SQ buah pemikiran Ari Ginanjar menjadi role model pelatihan spiritual yang berpedoman pada rukun iman dan rukun Islam banyak menghiasi pemahaman budaya dan etos kerja kembali kepada fitrah manusia seperti kasih sayang, kejujuran, tanggungjawab, peduli, disiplin, kebersamaan, kedamaian, kembali dalam garis orbit.

Kata Kunci: Sumber Daya Manusia

\section{PENDAHULUAN}

Krisis kepercayaan memunculkan pertanyaan di jutaan masyarakat. Pertanyaan yang hampir hampir tidak penah terjawab. Kepercayaan sudah hampir tidak ada dan orang dapat melakukan apa saja atas nama kebebasan berpendapat, tindakan yang sebelumnya dapat dijaga dengan baik dengan tingkat kepatuhan dan kesadaran yang tinggi dan merasa malu kalau orang melakukan pelanggaran. Krisis kepercayaan terjadi seiring dengan menghilangkanya kejujuran di banyak individu bangsa terutama terhadap dan di kalangan pemimpin. Antara krisis kepercayaan sudah demikian parah, hampir sebagian besar masyarakat, utamanya masyarakat 
kecil memandang masa bodoh siapa yang bakal memimpin mereka.

Era reformasi memunculkan perubahan tata nilai, moral, etika dan estetika periode akhir abad 20 hadir tanan dunia dengan adanya globalisasi yang menyentuh semua aspek kehidupan mulai dari nilai dan kehidupan, dunia kelihatan semakin sempit, dunia tidak ada sekat lagi, sehingga diperlukan tatanan baru yang sanggup menghadapi perubahan yang berlangsung cepat dan spartan.

Era digital telah melahirkan kemajuan yang luar biasa dibidang ilmu pengetahuan dan tehnologi. Lompatan terjadinya revolusi industri dengan ditemukan mesin uap membuka cakrawala berpikir perubahan mendasar dari tehnologi tradisonal dengan tehnologi mesin. Pada saat ini kita mengenal Tehnologi 4.0 dan berubah menuju revolusi tehnologi 5.0 dalam waktu relatif cepat, bila dibanding perubahan tehnologi 1.0 menuju 2.0 dan 3.0.

Perubahan semua membuat perubahan yang cepat dan mengeser perubahan norma, dan nilai nilai kehidupan dalam masyarakat, obyeknya adalah sumber daya manusia (SDM) yang terus bergeser mengikuti perubahan zaman. Tingkat kepuasaan hidup manusia sebagai pelaku utama juga mengalami perubahan yang cukup singnifikan.
Perubahan yang mengatasnamakan perubahan sebagai mana terjadi revolusi industri membawa dampak yang luar biasa mulai dari efisiensi dan efektifitas untuk mencapai hasil jauh lebih baik dari era sebelumnya. Tujuan akhir usaha adalah keuntungan (provit) yang didapat perhitungan ongkos produksi, dari bahan baku, pengolahan bahan, mausia sebagai pelaku yang menghasilkan barang dan jasa memahami hasil yang sesuai dengan kebutuhan serta keuntungan akan didapat dari proses panjang.

Dari penelusaran dan penelitian yang cukup panjang para peneliti Lembaga Leadership internasional yang bernama “ The Leadership Challenge " Telah melakukan survey karakteristik CEO, di 5 benua, Afrika, Amerika, Asia, Eropa. Responden diminta menilai dan memilih 7 karakteristik Ceo ideal bagi mereka selama 3 kali survei tahun, 1987,1995 dan 2007 Hornest (jujur) selalu berada diatas angka $830 / 0$.

Kejujuran menjadi ukuran untuk orang orang yang sukses telah diakui oleh dunia oleh semua agama, para ilmuwan lintas disiplin ilmu pengetahuan . Tulisan ini akan menyelusuri secara lebih jauh dan tulisan perdana pada jurnal saat ini. Ini merupakan sumbangan pemikiran penulis sebagai dosen dalam mengembangkan sumber daya manusia di Indonesia melalui 
jurnal dan penelitian dikemudian hari yang akan kami lakukan.

Jalan lurus maksudnya bersih atas karunia kepada kita hidayah, petunjuk, ide, ilham, kesempatan setiap saat, kesempatan tidak terhingga ,gerakan hati manusia, kesehatan, kepiawaian kecerdasan, ketangkasan ,kesabaran , keikhlasan ,ketawakalan segala sumber daya yang kami perlukan untuk melaksanakan ikhtiar dan usaha ini, sehingga berhasil maksimal menuju jalan lurus. ( Amin azis, The Power Al Fatikah, 2008)

Beberapa dekade belakang ini, kita banyak menyaksikan berbagai prinsip hidup yang menghasilkan berbagai tindakan manusia yang sangat beragam. Prinsip hidup dan diyakini itu telah menciptakan berbagai tipe pemikiran dengan tujuan nya masing-masing. Setiap manusia terbentuk sesuai prinsip yang dianutnya.

Melatih kebiasaan kognitif umumnya lebih mudah dibandingkan melatih kecerdasan emosi. Latihan mengoprasikan komputer, menghitung, menghafal daftar angka melatih kebiasaan kognitif yang berasal otak kiri, tetapi pelatihan yang membuat orang menjadi konsisten, memiliki konsisten, memiliki prinsip , mempunyai visi, memiliki kepercayaan diri , bersikap adil, bijaksana atau kreatif adalah kecerdasan emosi yang seharusnya juga dilatih dan dibentuk, tidak cukup hanya merupakan pelatihan kognitif seperti yang ada pada saat ini. Apabila berbicara kejujuran, maka berarti berbicara mental, berarti budaya kerja. Kejujuran berawal dari tumbuh dari lingkungan. Berkata jujur ,terbiasa dengan kejujuran, apabila ia tumbuh dalam suasana kejujuran pula. Anak yang tumbuh dalam suasana ketidakjujuran, terbiasa dengan kebohongan, maka akan mudah sekali ia bersifat tidak jujur. Dan pertumbuhan dari satu generasi kegenerasi berikutnya, bila berawal dari kejujuran, maka akan terbangun masyarakat yang disiplin dan baik. Bila kebalikannya, maka sifat generasi berikutnya akan bertambah buruk ( Mansyur, yusuf, Membumikan Rachmat Allah, 2007).

\section{METODE PENELITIAN}

Penelitian kualitatif dilakukan dalam penelitian ini, dilakukan pada kondisi alamiah dan bersifat penemuan. Dalam penelitian kualitatif, peneliti adalah instrument kunci. Karna itu peneliti harus mempunyai wawasan dan bekal teori yang luas jadi bisa bertanya, menganalisis dan mengkonstruksi objek yang akan dilteliti menjadi lebih jelas. Penelitian ini lebih menekankan pada makna dan terikat nilai. Hakikat penelitian kualitatif adalah mengamati orang dalam lingkungan 
hidupnya berinteraksi dengan mereka, berusaha memahami bahasa dan tafsiran

\section{HASIL DAN PEMBAHASAN}

Petuah dan wejangan jaman pertengahan abad 18 an pada masa penjajahan kolonial Belanda menjadi awal dari tulisan ini menjadi kenyataan dan benar terjadi pada saat ini. Pujangga agung kraton Mangkunegara Ronggo warsito yang semasa mudanya namanya Bagus Burhan beliau adalah cucu dari pujangga Yosodipuro 1 kraton Mangkunegara yang sama punya kemampuan membaca perjalanan bangsa ini melewati satu fase tertentu yang di tulis dalam bentuk tembang sinom. Yang sengaja penulis sampaikan pada awal penulisan jurnal ini ungkapkan melewati bahasa jawa asli dan diterjemahkan bebas.

Bahwa kehidupan ini laksana cermin besar bahwa kehidupan senantiasa berubah dan ukuran manusia hidup adalah kebaikan yang dijaga akan selalu dicacat dalam perjalanan hidup apa yang kita tanam hari ini akan berbuah pada masa yang akan datang. Kehidupan masa lalu bisa dijadikan cermin untuk merenung dan warisan itu akan terus diberikan pada generasi berikutnya apakah itu tuntunan agama, yang mencakup ibadah ritual, doa, nilai , norma, akhlak.
Didalam kehidupan di dunia ada yang memperhatikan keluasan hidup ini. Ada yang lebih mementingkan ketinggian nilai nilai hidup. Sedikit yang menyadari kedalamannya. Dunia ini sebenarnya tidak pernah berubah. Skenario dasar alur ceritanya tidak pernah berubah. Pelakunya berubah settingnya sama alurnya dan dekor berubah. Namun panggungnya tetap sama ceritanya itu juga ambisius dan ingin menguasai serta menganeksasi (Krisna, Anand ,Bhagawad Gita, 2000).

Anand krisna saseorang ahli spiritual keturunan india menjadi rujukan bagi mereka yang mempelajari kitab klasik yang dihubungkan dengan kehidupan sehabis melewati proses reformasi sistem ketanageraan sedang kacau, ketika kehilangan kesadaran dan akal sehat tidak bisa membaca keadaan semua berlangsung cepat sumber informasi tidak jelas, fitnah, umpatan sumpah serapah pada mantan penguasa dijumpai dengan mudah dan dipertontokan secara vulgar tulisan dan nasehat banyak menghiasi wacana pemikiran di tengah kegalauan setelah masa orde Baru. Banyak tulisan dan seminar serta tulisan sebagai bahan referensi dalam mengarungi kehidupan dan muncul pemikiran baru . Bagi yang masih bisa berfikir sehat dan punya kemampuan yang paripurna mulai membangun pemikiran baru dengan 
menyelami kehidupan khasanah klasik yang ditinggalkan maka muncul tulisan tulisan yang sengaja membangun kesadaran baru, mulai lintas disiplin ilmu apakah manajemen, siraman qolbu, sampai spiritual. Maka muncul tulisan Ustadz Yusuf mansyur, Abdullah Qimnastiyar, Emha Ainun Najib, Arifin ilham, Anand Krishna, Ari Ginanjar Agustian, William Wongso, Hermawan kertajaya, Tung Des Waringin Jati.

Mereka telah mendapatkan penjelasan tentang kebenaran, telah mendapat bimbingan, namun mereka tidak mendapatkan bimbingan, namun mereka tidak mendapatkan taufik untuk mengamalkan. Allah memiliki beberapa macam sarana hidayah, yang terangkum dalam 4 cara :

1. Kekuatan rasional dan emosional manusia.

2. Allah memberikan dalil-dalil yang dengan nya manusia dapat membedakan kebenaran dan keadilan.

3. Allah mengutus para nabi dengan membawa kitab-kitab samawi.

4. Wahyu, ilham dan mimpi mimpi yang benar.

Demikian demi keadilan-Nya Allah telah menganugrahkan 4 sarana hidayah kepada manusia sebagai pengantar menuju kebahagiaan mereka berupa :
1. Naluri.

2. Sarana Panca Indra.

3. Sarana Hidayah Akal.

4. Sarana Hidayah Agama. ( Aziz, Amin, Power Fatikah, 2008).

Filosuf berkebangsaan Italia Machiavelli (1468 - $1528 \quad)$ Mempropagandakan sistem tata kehidupan yang liberal secara religi maupun moral, sehingga aliran tidak peduli apakah tindakan politik yang dijalankan itu bermuara trick -trick, tipu daya, jujur atau tidak jujur asalkan tujuan tercapai. (Khaldun, Ibnu, Mukadimah, 2001).

Pada jurnal ini penulis tidak akan membahas secara khusus bahasan dan pemikiran Machiavelli yang banyak dianut diberbagai negara termasuk di inonesia .

Pada hasil survey yang diselenggarakan oleh Lembaga Leadersip Internasional yang bernama "The Leadership Challange“ mensurvei karakteristik CEO (Chief Executive Officer ) di lima benua:

Tabel penelitian

\begin{tabular}{|c|c|c|c|c|}
\hline No & karakteristik & $\begin{array}{l}\text { Respon } \\
\text { edisi }\end{array}$ & & \\
\hline & & 2002 & 1995 & 1997 \\
\hline 1 & $\begin{array}{l}\text { Hornest } \\
\text { (kejujuran) }\end{array}$ & 88 & 88 & 83 \\
\hline 2 & $\begin{array}{l}\text { Forward } \\
\text { Looking } \\
\text { (berpikir } \\
\text { Maju) }\end{array}$ & 71 & 75 & 62 \\
\hline 3 & $\begin{array}{l}\text { Competent } \\
\text { (Kompeten ) }\end{array}$ & 66 & 63 & 67 \\
\hline
\end{tabular}




\begin{tabular}{|c|c|c|c|c|}
\hline 4 & \begin{tabular}{|l} 
Inpiring \\
(memberi \\
Infirasi) \\
\end{tabular} & 65 & 68 & 58 \\
\hline 5 & \begin{tabular}{|l|} 
Intelegent \\
(Cerdas) \\
\end{tabular} & 47 & 40 & 41 \\
\hline 6 & \begin{tabular}{|l|}
$\begin{array}{l}\text { Fair minded } \\
\text { (adil) }\end{array}$ \\
\end{tabular} & 42 & 49 & 40 \\
\hline 7 & $\begin{array}{l}\text { Broad Minded } \\
\text { (adil) }\end{array}$ & 40 & 37 & 40 \\
\hline 8 & $\begin{array}{l}\text { Supportive } \\
\text { (mendukung) }\end{array}$ & 35 & 41 & 32 \\
\hline 9 & \begin{tabular}{|l|} 
Straight \\
Forward \\
(Terus terang/
\end{tabular} & 34 & 33 & 34 \\
\hline 10 & $\begin{array}{l}\text { Dependable } \\
\text { (Bisa } \\
\text { Diandalkan) } \\
\end{array}$ & 33 & 32 & 33 \\
\hline 11 & \begin{tabular}{|l|}
$\begin{array}{l}\text { Coorperative } \\
\text { (bekerjasama) }\end{array}$ \\
\end{tabular} & 28 & 28 & 25 \\
\hline 12 & \begin{tabular}{|l|} 
Determided ( \\
Tegas) \\
\end{tabular} & 24 & 17 & 17 \\
\hline 13 & $\begin{array}{l}\text { Imaginative } \\
\text { (Berdaya } \\
\text { Imajinasi) } \\
\end{array}$ & 23 & 28 & 35 \\
\hline 14 & $\begin{array}{l}\text { Ambitious } \\
\text { (Berambisi) }\end{array}$ & 21 & 13 & 21 \\
\hline 15 & \begin{tabular}{|l|} 
Courageneus \\
(Berani)
\end{tabular} & 20 & 29 & 27 \\
\hline 16 & $\begin{array}{l}\text { Caring( } \\
\text { Perhatian) } \\
\end{array}$ & 20 & 23 & 26 \\
\hline 17 & \begin{tabular}{|l} 
Matune \\
(dewasa)
\end{tabular} & 14 & 13 & 23 \\
\hline 18 & Loyal (Setia) & & & \\
\hline 19 & \begin{tabular}{|l} 
Self \\
Controlled \\
(Menguasai \\
Diri) \\
\end{tabular} & 8 & 5 & 13 \\
\hline 20 & $\begin{array}{l}\text { Independent } \\
\text { (Mandiri) }\end{array}$ & 6 & 5 & 10 \\
\hline
\end{tabular}

\section{Menerapkan Spiritual Capital}

Spiritual adalah suara hati spiritual atau collective unconscious yang menciptakan nilai-nilai (value) serta dorongan dari dalam (drive). Sifat-sifat Allah yang terletak pada spiritual center atau God spot.

Kemampuan akademik, nilai rapor, prediksi kelulusan pendidikan tinggi tidak bisa menjadi tolok ukur seberapa baik kinerja seseorang dalam pekerjaannya atau seberapa tinggi sukses yang mampu dicapai. Menurut makalah McCleland tahun 1973, berjudul "Testing For Competence Rather than Inteleligence" Dijelaskan tentang : Seperangkat kecakapan khusus seperti, empati, disiplin diri, dan inisiatif, akan membedakan antara mereka yang sukses sebagai bintang kinerja dengan yang sebatas bertahan di lapangan pekerjaan. Mereka menyimpulkan bahwa inti kemampuan pribadi dan sosial yang merupakan kunci utama keberhasilan seseorang sesungguhnya adalah kecerdasan emosi. Hal tersebut senada seperti yang dikatakan oleh Daniel Goleman bahwa Social awareness adalah pemicu awal gerakan berikutnya seperti Social Skill, Self Management, dan kemudian Self Awarencess di Sequence terakhir.

Selama ini banyak berkembang dalam masyarakat sebuah pandangan stereotife, dikotomi antara dunia dan akhirat. Dikotomi antar unsur kebendaan dan unsur agama, antara kasat mata dan tak kasat mata. Mereka lebih memilih keberhasilan dalam "Vertikal" 
Cenderung " Dinesbikan" atau sesuatu yang bisa demikian mudahnya ' Marginalkan' . Hasilnya, mereka unggul dalam kekhusukkan dzikir dan kekhitmatan berkontemplasi namun menjadi kalah dalam percaturan ekonomi , ilmu pengetahuan, sosial, politik dan perdagangan di alam " Horisontal ". Begitupun sebaliknya, yang berpijak hanya pada alam kebendaan, kekuatan berpikirnya tak pernah diimbangi oleh kekuatan spiritual. realitas kebendaan yang masih membelenggu hati, tidak memudahkankan bagi dirinya sendiri untuk berpijak pada nilai spiritualitas.

Dalam pandangan tentang penciptaan karakter menurut Buku Stephen R Covey, "taburlah gagasan, petiklah perbuatan, taburkan perbuatan, petik kebiasaan, taburkan kebiasaan , taburkan karakter, petiklah nasib. Artinya, untuk membangun karakter, tidak cukup hanya membaca buku bahkan pelatihan penuh selama satu minggu saja, namun dibutuhkan sebuah mekanisme pelatihan yang terarah dan tiada henti secara berkesinambungan.

Tujuan Konsep ESQ Ari Ginanjar Agustian adalah :

1. Membentuk manusia handal (khoiru Ummah) manusia adalah makhluk dua dimensi yang membutuhkan penyelarasan kebutuhan akan kepentingan jasmani dan rohani.

2. Mewujudkan manusia yang sukses dan bahagia sebuah kisah di Amerika Serikat bahwa ada seorang managing partner, biro hukum yang sukses dan kaya raya.

3. Sebagai formula membangun karakter manusia telah dikarunia IQ, Es dan SQ sebagai bahan dasar, tetapi tidak tahu bagaimana cara mengolahnya secara bersamaan dan terintegrasi.

Kejujuran dapat diartikan dengan menyampaikan segala sesuatu sesuai dengan kenyataan yang ada, baik dalam perkataan, perbuatan, tulisan atau pun isyarat, dalam arti meliputi seluruh aktifitas sebagai muslim, dimulai dari niat sampai kepada pelaksanaannya. Setiap orang harus menjaga perkataannya, tidak berkata kecuali yang benar dan secara jujur. Jujur dalam perkataan merupakan jenis jujur yang paling terkenal dan jelas. Dia juga harus menghindari perkataan yang di buat-buat, karena hal ini termasuk jenis dusta, kecuali jika ada keperluan yang mendorongnya berbuat begitu dan dalam kondisi-kondisi tertentu bisa mendatangkan kemaslahatan ( Shihab, Quraisy ,2005) 


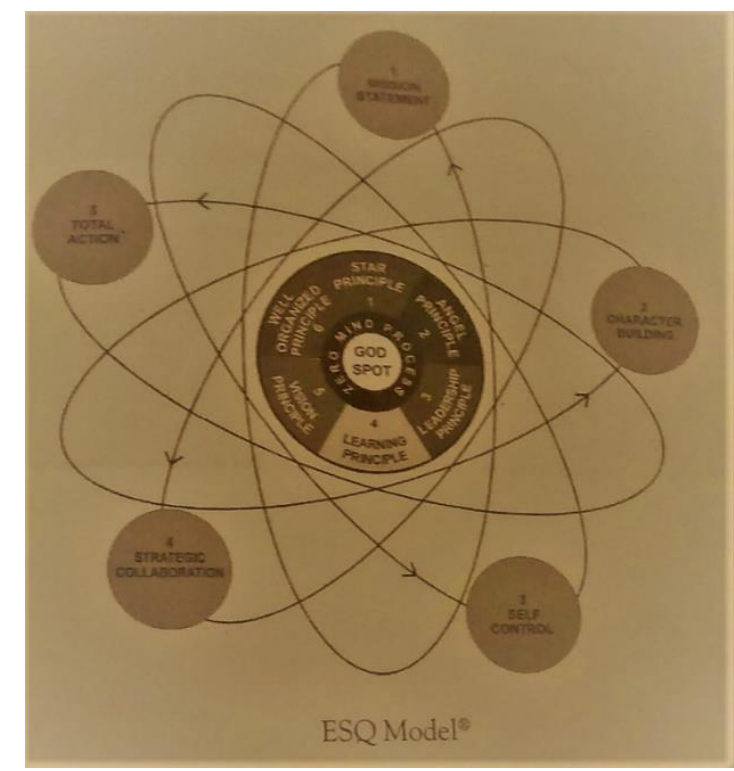

Keterangan Gambar :

Bagian Satu : God Sport dan Zero Mind

Proses Untuk membangun Kecerdasan

Spiritual (SQ)

Bagian Dua : Mental Building Untuk :

Membangun Kecerdasan

Emosi (SQ).

1. Star Principle.

2. Angel Principle.

3. Leadership Priciple.

4. Learning Principle.

5. Vision Principle.

6. Well Organized Principle.

Bagian Tiga : Personel Strength

Langkah 1.

1. Mission Statement.

2. Character Building.

3. Self Controling.

Bagian Empat : Social Strength

Langkah Fisik 2.

4. Strategic Collaboration.

5. Total Action.
Untuk lebih menyederhanakan, inilah 7 spiritual care volues (nilai Dasar ESQ yang yang diambil dari asmaul Husna yang dijunjung harus dijunjung tingg sebagai bentuk pengabdian manusia kepada sifat Allah yang terletak pada pusat orbit (GOD SPOT) :

1. Jujur, adalah perwujudan pegabdian manusia kepada sifat Allah, Al Mukmin.

2. Tanggung Jawab, Adalah wujud pengabddian manusia kepada sifat Allah, Al Wakiil.

3. Disiplin, Adalah wujud pengabdian manusia kepada sifat Allah, Al Matiin.

4. Kerjasama, Adalah wujud pengabdian manusia kepada sifat Allah, Al Jaami'.

5. Adil, adalah wujud pengabdian manusia kepada sifat Allah, AL 'ADL.

6. Visoner, Adalah wujud pengabdian manusia kepada sifat Allah, AL Aakhir.

7. Peduli, adalah wujud pengabdian manusia kepada sifat Allah, As Sami' dan Al Bashir.

Ketujuh sifat yang harus dijadikan Values atau 'Nilai' dimana akan memberikan 'Meaning' atau nilai bagi yang melaksanakanya, di disamping nilai nilai yang lain yang berjulah 99 sebagai sumber pengabdian, ( Ginanjar Ari, ESQ, 2005). 
Teori perubahan sosial yang berlaku dapat dideskripsikan, ketika modernism merambah menjadi alat ukur kemajuan ummat manusia . Dari kehidupan tradisional menuju kehidupan modern, ditunjukkan perubahan kehidupan agraris kehidupan mesin. Pongahnya manusia mulai tidak rasional dan meninggalkan sisi spritualitas. Lama berada dibawah rasionalitas dan meniadaakan sisi spritualitas tersebut, ummat manusia merasakan ada ruang kosong yang tidak terisi dan membuat akibat dalam sejarah kehidupan manusia.

Kekosongan tersebut berada di wilayah jiwa. Manusia hidup tidak hanya dengan raga, tetapi juga jiwa.

Dampak hidup yang berlandaskan semata dengan rasionalitas, telah membawa sebagian potret kehidupan ummat manusia ketidak seimbangan . Labih, nihil. Kekosongan itu membuat manusia merasakan ketidakmampuan mencapai hakikat kebahagiaan yang sebenarnya. Titik jenuh rasionalitas itu dibaca oleh filosof Jacques Derrrida (1930 - 2004 ) sebagai bentuk munculnya posmodernisme.

Posmodernisme yang tumbuh ditengah masyarakat yang telah bergelimang dengan modern, rasionalitas, materialisme, yang awalnya seakan -akan tidak membutuhkan spiritualisme akhirnya mendekatkan diri terhadap spiritualitas.

Spiritualitas tersebut kita kenal dalam kehidupan adalah agama. Menjawab kebutuhan dasar jiwa manusia, pengakuan atas kekuatan lahir di luar diri manusia. Beranjak dari situlah, para filosof mengambarkan situasi kekinian manusia yang menyadari arti penting spirit dalam kehidupan. Hidup tak melulu dengan akal semata. Dalam konteks ini, tradisi keagamaan kembali di jemput, dikaji, diteliti, dijadikan landasan kehidupan. Hal ini terjadi dibelahan dunia yang paling majupun. ( Khusairi, Abdullah, Hipokrisi dalam Posmodernisme, 2006 ).

Krisis multi dimensi yang melanda tanah air adalah sebagai akibat dari usaha pemisahan kehendak Allah yang bersemayam kehendak hati nurani manusia (Got Spot Atau fitrah Manusia) dengan kehendak manusia yang cenderung egois. Hidupnya telah menyimpang dari garis edar yang fitrah, tujuan hidupnya telah mengorbit diluar garis edar, melawan mekanisme alam, serta menentang kekuatan sang maha perkasa.

Ikrar kalimat syahadat membentuk sebuah tekad dan komitmen yang bulat, perjanjian yang mengikat antara manusia dengan Tuhan penciptanya. Inilah sumber kekuatan tak terperi bagi orang yang beriman dan bertaqwa yang akan 
memunculkan keberanian dan keyakinan, optimisme juga ketenangan batin. Bentuk sinergi anatara manusia yang beriman dan mengabdi pada Robb Nya dengan sifat Allah yang maha digdaya, bisa kita lihat dalam diri Muhammad. Ia telah menjalin ikatan syahadat dengan Allah SWT dan berhasil mengubah wajah dunia dengan Syahadatnya. Kemudian misi ini diteruskan para Khulafaur Rosidin yang mampu mendirikan sebuah imperium terbesar yang membentang dari perbatasan india hingga samudra atlantik, (Ginanjar, ari, ESQ, 2007).

Tujuan dasar spiritual (Core Purpuses) serta nilai-nilai dasar spiritual (Core Values) itu yang dipertahankan ditengah perubahan budaya, kebiasaan, strategi dan kebijakan. Maka 5 Rukun Islam mampu menjaga Core Values dan Core Porposes selalu digaris edar-Nya:

1. Core Purposes atau Allah tujuan dasar spiritual manusia adalah pengabdian hanya kepada Allah, bukan jabatan, uang, harta atau kelompok.

2. Core Values atau dasar spiritual pada Got sport dilatih dengan pengulanggan nilai-nilai luhur atau sifat Allah dalam Shalat 5 waktu, sehingga nilai-nilai mulia seperti kasih sayang, kejujuran, tanggung jawab, disiplin, kebersamaan, dan kedamaian terinternalisasi melalui pengulangan ucapan dan gerakan dalam shalat.

3. Puasa berfungsi melindungi serta memerangi faktor -faktor perusak nilai dasar/tujuan dasar spiritual. Disini pentingnya wujud perang melawan hawa nafsu, yakni menghentikan perusakan nilai -nilai dasar fitrah suara hati pada Got Spot. Dengan dihentikan dan dikendalikan hawa nafsu untuk mengembalikan tujuan dasar hidup kegaris orbit semula, yaitu pengabdian Kepada Allah, Inilah makna perang melawan hawa nafsu dalam puasa itu sebenarnya.

4. Fitrah manusia berupa suara hati Ilahiah dalam God Spot, harus pula di zakatkan. Dan tidak boleh disimpan didasar hati. Nilai-nilai Spiritual itu harus dikeluarkan dalam bentuk langkah nyata, bukan dalam bentuk Value namun dalam bentuk Action, bukan hanya nilai spiritual namun aksi. Maka Substansi dibayarkan Zakat adalah : "Keluarkan seluruh potensi fitrah dalam diri kita, Zakat fitrah yang kita miliki, serta zakatkan apa yang dalam Got Spot Kita”.

Keluarkan semua potensi spiritual dalam Got Spot -mu menjadi amal soleh, zakatkan fitrahmu menjadi langkah nyata. 
5. Kerahkan seluruh potensi spiritual dalam Got Spotmu dengan sepenuh hati jadikan langkah nyata seperti haji.

Kelima langkah ini yang menjadi pembimbing dalam setiap gerak, sekaligus sebagai mekanisme penjagaan serta memelihara nilai dasar spiritual serta tujuan dasar spiritual ditengah perubahan budaya, kebiasaan, juga tehnologi. ( Ari Ginanjar, 2007).

Sufi merupakan aktualisasi dari nilai nilai rabbaniyyah, dalam kehidupan, Sufi bukanlah sikap anti dunia, dalam kehidupan moder saat ini, sosok manusia dengan segala kesibukannya di dunia dapat menjadi sudi, seorang karyawan, pebisnis, dapat menjadi dengan pakaian modern seperti berdasi, kemeja, jas dan sebaginya.

Fadlan memandang ESQ efektif mencerdaskan masyarakat. Banyak yang mencoba mengkritisi perkembangan ESQ, Mulai dari penilaian miring hingga kritik terhadap praktek pelatihan yang dilakukan, alangkah bijak memahami dengan cara masuk serta mempelajari lebih dalam. ESQ memang digemari, dibutuhkan, menjawab persoalan masyarakat yang butuh siraman rohani. Adapun pelatihan ESQ adalah:

1. ESQ basic training.

Pada training awal peserta akan memperoleh pemahaman tentang konsep dasar ESQ serta merasakan pengalaman spiritual yang akan mengubah kehidupan kearah yang lebih baik.

2. ESQ Mission Statement.

Training ini membantu peserta untuk memiliki visi yang jelas dan misi kuat.

3. ESQ Character Building.

Melalui training ini peserta akan menjadi seorang pribadi yang memiliki karakter kuat dan tangguh.

4. ESQ Self Control.

Kemampuan untuk mengendalikan diri serta mengalahkan semua kelemahan adalah hasil yang akan peserta peroleh dari training ESQ self Control.

\section{ESQ Strategi Collaboration.}

Peserta training akan diajak untuk menemukan potensi yang tak ternilai yaitu kolaborasi serta menciptakan tim kerja yang solid.

\section{ESQ Star Leader}

Untuk mewujudkan sebuat ini menjadi kenyataan maka diperlukan kemampuan untuk mengeksekusi sebuat gagasan.

\section{ESQ Total Action.}

Peserta akan diminta mengajukan sebuah ide proyek sesuai dengan bidang dan keahlian masing masing untuk terwujudnya Indonesia Emas.

Pada saat zaman berubah, kebutuhan telah mengantarkan kehidupan yang rasional manusiapun berubah. Modernisasi telah mengantarkan kehidupan yang rasional sebagai landasan kehidupan 
ternyata menemui titik jenuh manusia. Dimensi kehidupan rasional dirasakan hambar ketika dimensi spiritual tidak terpenuhi. ESQ menjawab dimensi tersebut . sehingga kehadirannya dirasakan manfaatnya . Dalam kajian tasawuf modern, ESQ adalah model yang paling pas dan sesuai zaman. Dalam kajian pendidikan ESQ adalah model pembelajar efektif. Mampu merubah sikap, cara pandang dan tindakan individu.

Dimensi illahiyah yang menjadi kebutuhan jiwa manusia memang sudah diperdebatkan dalam wilayah akademik. Terhadap sikap mental spiritual kaum modernis yang menghamba pada akal ternyata tidak membawa kebahagiaan hakiki. Dimensi rohani yang ditinggalkan membutuhkan keseimbangan. Agama pada dasarnya hadir untuk menjawab kepentingan rohani tersebut. Dimana kebahagiaan, cinta , juga kedamaian hidup hanya dapat diraih melalui kebahagaian rohani, bukan materi. Secara materi, telah dibuktikan, mereka yang meraih kehidupan materialism tidak begitu sungguh-sungguh mendapat Kebahagiaan. Sebaliknya, kehidupan materialism diakhiri dengan kekosongan jiwa. Kekosongan tersebut membuat sifat ketakutan, keresahan, ketentraman muncul mengisi kehidupan. Akibatnya, untuk menengkan jiwa yang kosong dan liar tersebut, pelarian kepada narkotika dan obat-obatan terlarang salah satu jalan pintas. Jalan pintas membawa kemudlaratan yang membawa kehancuran kehidupan. (Yunus, Yulizal, Indonesia Ujung Kata, 2012).

\section{PENUTUP}

Kecerdasan emosi atau " Emotional Intelengence" merujuk pada kemampuan serta mengenali perasaan kita sendiri, juga perasaan orang lain. Kemampuan memotivasi diri sendiri dan kemampuan mengelola emosi diri sendiri dengan hubungannya dengan orang lain.

Nilai produktivitas adalah kemampuan seseorang untuk mengolah akal dan budinya secara bijak dalam bentuk unjuk kerja, untuk memperoleh sesuatu yang maksimal yang didukung oleh integritas kepribadiannya. Hal itu akan melahirkan respek terhadap prestasi individu dalam sebuah masyarakat. Produktivitas selain diukur kemampuan individu tersebut dalam menghasilkan buah dari produktivitasnya juga bila hal itu dicapai melalui cara cara hidup secara profesional, jujur dan melalui persaingan yang sehat dan wajar, masa depan sebuah depan sebuah masyarakat adalah resultan dari pencapaian prestasi masyarakat. Masyarakat akan mengutuk praktik penyuapan, persaingan tidak sehat dan 
perilaku curang lainnya yang akan ditolak oleh kelembagaan hukum yang disusun untuk itu. Produktivitas yang berintegritas ini tumbuh dari nilai penghargaan masyarakat terhadap kerja keras dan dedikasi seseorang terhadap pekerjaan, karena sebagai muslim bekerja adalah ibadah, karenanya perilaku bekerja dan produktif secara jujur dan berintegritas adalah ibadah nonritual yang sesungguhnya.

Sikap terpuji akan menjadi sikap baru masyarakat seperti mengontrol belanja sesuai dengan kemampuannya, memproduksi barang dan jasa yang kompetitif dipasar internasional menggunakan tehnologi informasi untuk membangun jaringan dengan warga lain dan sejenisnya.

Tanggung jawab sosial, dengan nilai-nilai ini masyarakat memiliki tanggung jawab sosial untuk memerangi kemiskinan, keterbelakangan, dan ketimpangan antar warga masyarakat. Kesadaran bahwa diantaranya pendapatan yang kita peroleh masyarakatnya. Kesadaran bahwa di antara pendapatan yang kita peroleh ada sebagian hak orang lain, akan menciptakan kesadaran etis bahwa zakat, infaq dan sadaqoh adalah kewajiban pada yang berhak. Dengan jalan ini kita bangsa ini dapat mengurangi ketergantungan pada bangsa lain dan menciptakan kesejahteraan sendiri.

Kebohongan kembali melakukan kesombongan ,keculasan juga akan kembali terjadi sekali dua kali, bahkan lebih, shalat sering lagi dilakukan, tetapi sering kita melakukan diundurkan, apalagi shalat tahajjud tidak pernah lagi.

Selama ini terjadi semacam stereotif, bahwa Ihsan, rukun iman dan Rukun Islam adalah untuk keperluan akhirat, dan ajaran barat untuk keberhasilan dunia. Akibatnya bagi orang yang cenderung pada kepentingan akhirat, mereka akan "bergeser ke arah kanan" tetapi terkadang terlalu kekanan, yang mengakibatkan "Kaum Sekuler Kanan “. . Merekalah yang kemudian mengabaikan tugasnya semasa didunia. Sebaliknya kelompok yang terlalu berorientasi pada dunia, "bergeser ke arah kiri" dan rentan kearah kiri. Akibatnya terbentuk "kelompok sekuler kiri" yang mengesampingkan kepentingan akhirat atau spiritual.

Kelompok sekuler kiri diharapkan bergerak kekanan, dan sekuler kanan bergerak kekiri, sehingga berada pada titik temu keseimbangan. Keberhasilan sejati baik didunia maupun akhirat, serta kebahagian hakiki, baik lahiriah maupun batiniah, melalui mekanisme Ihsan. Tingkat kecerdasan emosi sesorang sangat bergantung pada kemampuan untuk 
memahami perasaan diri sendiri maupun perasaan orang lain. Kecerdasan emosi adalah kemampuan merasakan, memahami, dan secara efektif merasakan daya serta kepekaan emosional sebagai energi,informasi, koneksi serta pengaruh yang manusiawi.

Apabila lebih lanjut lagi kita bertanya kepada mereka, "Dorongan emosi apakah Itu ?" dan "tolong sebutkan satu persatu jenis suara hati tersebut...? maka akan sulit bagi ahli ahli barat tersebut mampu menjelaskan satu persatu. Tetapi bila mempelajari dan merasakan satu persatu dorongan suara hati berdasarkan Asmaul Husna maka akan mampu mendeteksi setiap dorongan dari suara hati satu persatu dengan jelas.

\section{REFERENSI}

Amin, Aziz, Power Of Al Fatikah, , Pustaka Al Kautsar, Jakarta, 2010,

Anwar, Rosihan, Akhlah Tasawuf,CV Pustaka Setia, jakarta, 2005.

Carter, Stephen L, Integritas, Pustaka Sinar Harapan, Jakarta, 1999.

Ginanjar, Ari, E S Q, Arga, Jakarta, 2005. Ginanjar, Ari, E S Q Power, Arga, Jakarta, 2009.

Gymnastiar, Abdullah, Jagalah Hati, Khalifah Offcet, Bandung, 2006.

Purwadi, Serat Dewa Ruci, Kreasi Wacana, Yogyakarta, 2007.

Khaldun, Ibnu , Mukadimah, Pustaka Al Kautsar, Jakarta, 2001.

Krisna, anand, Bhagavad Gita, Gramedia Utama, Jakarta, 2000.
Mansyur Yusuf, Membumikan Racmat Allah, Zikrul Hakim, Jakarta, 2007.

Mansyur, Yusuf, Mencari Tuhan Yang Hilang, Zikrul Hakim, Jakarta, 2007.

Mulkan, Munir, Abdul, Syech Siti Jenar, Kreasi Wacana, Yogyakarta, 2002.

Mulkan, Munir, Abdul, Syech Siti Jenar, Kreasi Wacana, Yogyakarta, 2005.

Quth, Muhammad, Jahiliyah Masa Kini, Pustaka, Bandung, 1985.

Widyawati, Wiwin, Serat Kalatida, Pura Pustaka, Yogyakarta, 2009.

Rachmat, jamaludin, Meraih kebahagian, Sembiosa Rekatama, Bandung, 2004.

Wibisono, Chistianto, Gerhana Hati Nurani, Gramedia Utama, Jakarta, 2012.

Yunus, Yusrizal, Indonesia Diujung Kata, Cv. Putri Tunggal, Padang, 2012).

Yusuf, M., Teknologi, I., \& Rakyat, B. (2022). EFEECT OF SHARIA COMPLAINCE , GOVERNANCE, AND SOCISL RESPONSIBILITY ON BUSINESS SUSTAINABILITY : MEDIATING ROLE OF BUSNIESS GROWTH. 28(1), 2686. 